\title{
Craniopharyngioma in Adults - Neurosurgical Outcome
}

\author{
Cristina CAPATINA ${ }^{1,2}$, Anda DUMITRASCU², Andra CARAGHEORGHEOPOL ${ }^{2}$, Vasilie CIUBOTARU³ \\ Catalina POIANA ${ }^{1,2}$
}

\begin{abstract}
Background: Craniopharyngiomas are rare tumors developed in the area of the sella turcica and especially the suprasellar region. Despite their benign histological nature they are locally aggressive and surgical intervention is a major challenge due to the risk of damaging critical neural and vascular neighbouring structures. Objective: To study the postsurgical evolution of craniopharyngioma in adults after total or partial surgical resection. Material and methods: We performed a retrospective review of adult craniopharyngioma patients evaluated and followedup in the Pituitary Diseases Department of the National Institute of Endocrinology in Bucharest between 1998 and 2018. Results: A total of 60 patients (39.62 \pm 15.6 years-old) diagnosed with craniopharyngioma were included. All underwent initial surgery (68.3\% transcranial, 31.7\% transsphenoidal approach). Gross total resection (GTR) was achieved in 21 cases (35\%), in all the others partial resection was obtained (non-GTR). Immediate non-threatening postsurgical complications were anosmia (in 2 cases), cerebrospinal fluid-CSF leak (3 cases), subdural hematoma ( 2 cases). After surgery 13 cases (21.66\%) had cognitive impairment (2 with GTR, 11 with non-GTR), 14 (23.3\%) had hypothalamic syndrome (diurnal sleepiness, appetite and memory dysfunction- present in 1 case with GTR, 13 with non-GTR), 27 cases (45\%) reported lethargy (7 GTR, 20 non-GTR), 24 (40\%) complained of headaches (6 GTR, 18 nonGTR). All these complications were significantly more frequent in cases with incomplete tumor resection compared to those with GTR: $p=0.000 ; 0.000 ; 0.036$ and 0.009, respectively. Conclusions: Craniopharyngioma as well as its treatment are associated with very significant morbidity. Aggressive surgical resection with the aim of GTR is possible in a significant percentage of cases and if it is carefully considered in view of the surgically perceived risk of neurologic injury it is associated with lower postsurgical morbidity.
\end{abstract}

Keywords: craniopharyngioma, adult, neurosurgery, resection

\section{Rezumat}

Introducere: Craniofaringioamele sunt tumori rare dezvoltate în zona șeii turcești și mai ales suprașelar. În ciuda caracterului lor histologic benign, sunt tumori agresive local și intervenția chirurgicală este de multe ori dificilă din cauza riscului de afectare a structurilor neurovasculare vitale din vecinătate. Obiectiv: Studierea evoluției postoperatorii a craniofaringioamelor la adulți după rezecția totală sau parțială. Material și metode: Am efectuat un studiu retrospectiv al pacienților adulți cu craniofaringiom evaluați și urmăriți în Secția de Patologie Hipofizară și Neuroendocrină a Institutului Național de Endocrinologie din București în perioada 1998-2018. Rezultate: Am inclus 60 de cazuri (vârsta 39,62 15,6 ani) diagnosticate cu craniofaringiom. Toti pacienții au fost operați (68,3 \% abord transcranian, 31,7\% transsfenoidal). Rezecția totală macroscopică (RT) a fost obținută în 21 de cazuri (35\%), la celelalte

1 Department of Endocrinology, "Carol Davila" University of Medicine and Pharmacy, Bucharest, Romania

2 "C.I.Parhon" National Institute of Endocrinology, Bucharest, Romania

${ }^{3}$ Department of Neurosurgery, „Bagdasar Arseni” Emergency Hospital, Bucharest, Romania

\section{Corresponding author.}

Cristina Capatina, „C.I. Parhon“ National Institute of Endocrinology, Bucharest, Romania.

E-mail: cristina.capatina@yahoo.com 
s-a obținut rezecție parțial (non-RT). Complicații postoperatorii imediate non-severe au fost anosmia (2 cazuri), rinolicvoreea (3 cazuri), hematom subdural (2 cazuri). Postoperator, 13 cazuri $(21,66 \%)$ au dezvoltat afectare cognitivă (2 cu RT, 11 non-RT), 14 (23,3\%) sindrom hipotalamic (somnolență diurnă, tulburari de apetit și memorie prezent la 1 caz cu RT, 13 cu non-RT), 27 de cazuri (45\%) au raportat letargie (7 RT, 20 non-RT), 24 (40\%) cefalee (6 RT, 18 non-RT). Toate aceste complicații au fost semnificativ mai frecvente în cazurile cu rezectie tumorală parțială comparativ cu cele cu RT: $p=0,000 ; 0,000 ; 0,036$ respectiv 0,009. Concluzii: Craniofaringiomul și tratamentul său sunt asociate cu morbiditate semnificativă. Rezecția chirurgicală agresivă cu scopul extirpării complete a tumorii este posibilă într-un procent semnificativ de cazuri și dacă este decisă numai după atenta cântărire a riscului de afectare neurologică postoperatorie este asociată cu morbiditate scăzută.

Cuvinte cheie: craniofaringiom, adult, neurochirurgie, rezecție.

\section{INTRODUCTION}

Craniopharyngioma is a histologically benign tumor derived from remnants of Rathke's pouch, developing in the area of the sella turcica and the suprasellar area but with a clinically more aggressive behavior compared to most other human benign tumors and associated with considerable morbidity. Neurosurgical intervention is initially recommended but despite recent progresses in surgical techniques the intervention is frequently challenging due to tumor characteristics (large size, frequent adherence to critical neurovascular neighboring structures). Long-term tumor control is therefore difficult despite multimodal modern treatment. However, the most important predictive factor for longterm, tumor control and recurrence-free survival is the extent of the initial surgical resection ${ }^{1,2}$. Therefore some advocate gross total resection (GTR) as the aim of surgery in virtually all cases; however aggressive surgical resection has been associated with worse neuroophtalmological, endocrinological, metabolic and behavioral complications in certain cases therefore careful individual assessment of risk (evaluating tumor attachment to or infiltration of the hypothalamus or vascular structures, important calcifications aso) is essential for surgical planning ${ }^{2}$.

\section{Objective}

To assess the neurosurgical results of a cohort of adults with craniopharingioma diagnosed and followed -up in the Department of Pituitary and Neuroendocrine Diseases of the „C.I. Parhon” National Institute of Endocrinology.

\section{Material and methods}

We performed a retrospective review of adult craniopharyngioma patients evaluated in our department at the National Institute of Endocrinology in Bucharest between 1998 and 2018. We included for retrospective file review all patients with histologically confirmed craniopharyngioma. We collected demographic data (age at diagnosis, sex, height, weight, BMI), symptoms at diagnosis, visual and endocrine evaluation at baseline and during follow-up. We also reviewed the type of surgery, the extent of tumor resection, data regarding postoperative morbidity during follow-up.

The tumor was assessed by MRI whenever possible but also by $\mathrm{CT}$ in a significant percentage of cases (especially at the beginning of the study period). The brain scans were obtained at 3 months after surgery, then at 6-12 months interval depending on the presence of tumor remanant and its behavior.

\section{STATISTICAL ANALYSIS}

SPSS for Windows version 19.0 (SPSS Inc., Chicago, IL, USA) was used for statistical analysis. The MannWhitney U-test was applied for the comparisons of data between subgroups of the patients (data were not normally distributed). The chi-square test was used for the comparison of discrete variables. P-values $<0.05$ were considered as statistically significant.

\section{RESULTS}

A total of 60 adult patients with histologically confirmed craniopharyngioma (pathological analysis of the tumor sample resected at the time of the neurosurgical intervention) were included.

There were 38 males (63.3\%) and 22 females (36.7\%), aged 18-72 years-old (mean \pm SD 38.62 \pm 15.67 , median 34.5 years) followed-up for a median of 4 years (range 1-21 years) from the time of diagnosis until either latest presentation.

At the time of diagnosis the visual field was impaired in 44 cases (73.3\%) and the visual acuity was decreased in 43 (71.7\%). 35 cases (58.3\%) had at least some 
degree of pituitary insufficiency at diagnosis. Other symptoms were variably present at the time of diagnosis-see table 1.

The maximal tumor diameter at diagnosed was comprised between 1.1 and $8.2 \mathrm{~cm}$ (mean \pm SD $2.73 \pm 1.03$ $\mathrm{cm}$; median $2.3 \mathrm{~cm}$ ). In 2 cases the tumor was described confined to the sella, in 5 cases within the sella and suprasellar area and in all other cases the location was mainly suprasellar. 39 tumors (65\%) had cystic component while 32 (53.3\%) had intratumoral calcifications.

All cases underwent initial surgery $(68.3 \%$ by transcranial, $31.7 \%$ by transsphenoidal approach). The approach was decided by the neurosurgeon based on the characteristics, precise location of the tumor and own experience. Tumors operated by transcranial approach were slightly larger compared to those operated transsphenoidally (mean maximal diameter 3.25 $\mathrm{cm}$ vs $2.24 \mathrm{~cm}, \mathrm{p}=0.043$ ).

Gross total resection (GTR) was achieved in 21 cases (35\%), in all the others maximal resection was attempted within safety limits (non-GTR). In many non-GTR cases subtotal resection could not be achieved either and partial resection was obtained: the median diameter of the remnant tumor was $2 \mathrm{~cm}$ (mean $1.8 \mathrm{~cm}$, SEM 0.215).

Immediate postsurgical complications were anosmia (in 2 cases, both with non-GTR), CSF leak (3 cases, all with GTR), subdural hematoma (2 cases: one GTR, one non GTR), cranial nerves (CN) palsy in 2 cases. The numbers in the GTR and non-GTR subgroups were too small to check for statistical significance.

A significant number of cases developed postoperative diabetes insipidus (DI), mostly transient but also permanent in some cases (Table 2 and Figure 1).

Table 1. The most frequent symptoms at the time of diagnosis

\begin{tabular}{|l|c|c|}
\hline \hline & No cases & $\begin{array}{c}\text { Percentage of } \\
\text { all cases }\end{array}$ \\
\hline Headache & 50 & 83.3 \\
\hline Cranial nerves palsies & 7 & 11.7 \\
\hline Photophobia & 4 & 6.7 \\
\hline Hydrocephalus & 8 & 13.3 \\
\hline Nausea/vomiting & 10 & 16.7 \\
\hline Depression & 2 & 3.3 \\
\hline Convulsions & 1 & 1.7 \\
\hline Diabetes insipidus & 5 & 8.3 \\
\hline Hypopituitarism & 35 & 58.3 \\
\hline Visual field (VF) defect & 44 & 73.3 \\
\hline Visual acuity (VA) impairment & 43 & 71.7 \\
\hline
\end{tabular}

After surgery 13 cases (21.66\%) reported subjective cognitive impairment: slowing or difficulty in speech, slowing in reasoning and thinking, memory impairment ( 2 with GTR, 11 with non-GTR). 14 cases (23.3\%) had hypothalamic syndrome (diurnal sleepiness, appetite dysfunction- present in 1 case with GTR, 13 with non-GTR). 27 cases (45\%) reported lethargy (7 GTR, 20 non-GTR), 24 (40\%) complained of headaches ( 6 GTR, 18 non-GTR). All these complications were significantly more frequent in cases with incomplete tumor resection compared to those with GTR: $\mathrm{p}=0.000 ; 0.000 ; 0.036$ and 0.009 , respectively - (Table 2 and Figure 1).

The visual function was improved after surgery in a minority of cases: VF improved in 19\% of GTR cases and only $7.6 \%$ of non-GTR cases. While in most cases the visual impairment remained stable, there were also cases experiencing worsening of VF defect after surgery $19 \%$ of GTR cases, $46.15 \%$ of non-GTR cases $(\mathrm{p}=0.011)$ (Figure 2).

During follow-up a total of 17 cases were diagnosed with tumor recurrence: 5 with an initial macroscopic GTR, the other 12 from the group with non GTR at initial surgery. Out of those 12 patients only 4 had received adjuvant postoperative radiotherapy. The patients with recurrence and those without recurrence during follow-up were no statistically different with respect to age, sex, tumor diameter (before or after surgery), surgical approach, pituitary function-data not shown.

Table 2. Postsurgical complications in the GTR and non-GTR subgroups (number of cases and percentage of all cases in each subgroup); na=not assessed; ns=not significant

\begin{tabular}{|l|c|c|c|}
\hline & GTR & Non-GTR & p \\
\hline Worsening pit function & $19(90.47 \%)$ & $29(74.35 \%)$ & $0.000 *$ \\
\hline Permanent DI & $10(47.61 \%)$ & $9(23.07 \%)$ & $0.002 *$ \\
\hline Transient DI & $5(23.80 \%)$ & $14(35.89 \%)$ & $0.04 *$ \\
\hline Lethargia & $7(33.33 \%)$ & $20(51.28 \%)$ & $0.036 *$ \\
\hline Headache & $6(28.57 \%)$ & $18(46.15 \%)$ & $0.009 *$ \\
\hline Hyperphagia & $5(23.8 \%)$ & $6(15.38 \%)$ & ns \\
\hline Subdural haematoma & $3(14.28 \%)$ & 0 & na \\
\hline Cognitive impairment & $2(9.52 \%)$ & $11(28.2 \%)$ & $0.000 *$ \\
\hline Sleep disturbances & $1(4.76 \%)$ & $13(33.3 \%)$ & $0.000 *$ \\
\hline CN palsy & 0 & $2(5.12 \%)$ & na \\
\hline Anosmia & 0 & $2(5.12 \%)$ & na \\
\hline None & $6(28.57 \%)$ & $17(43.58 \%)$ & $0.006 *$ \\
\hline Total no of cases & $21(100 \%)$ & $39(100 \%)$ & \\
\hline
\end{tabular}




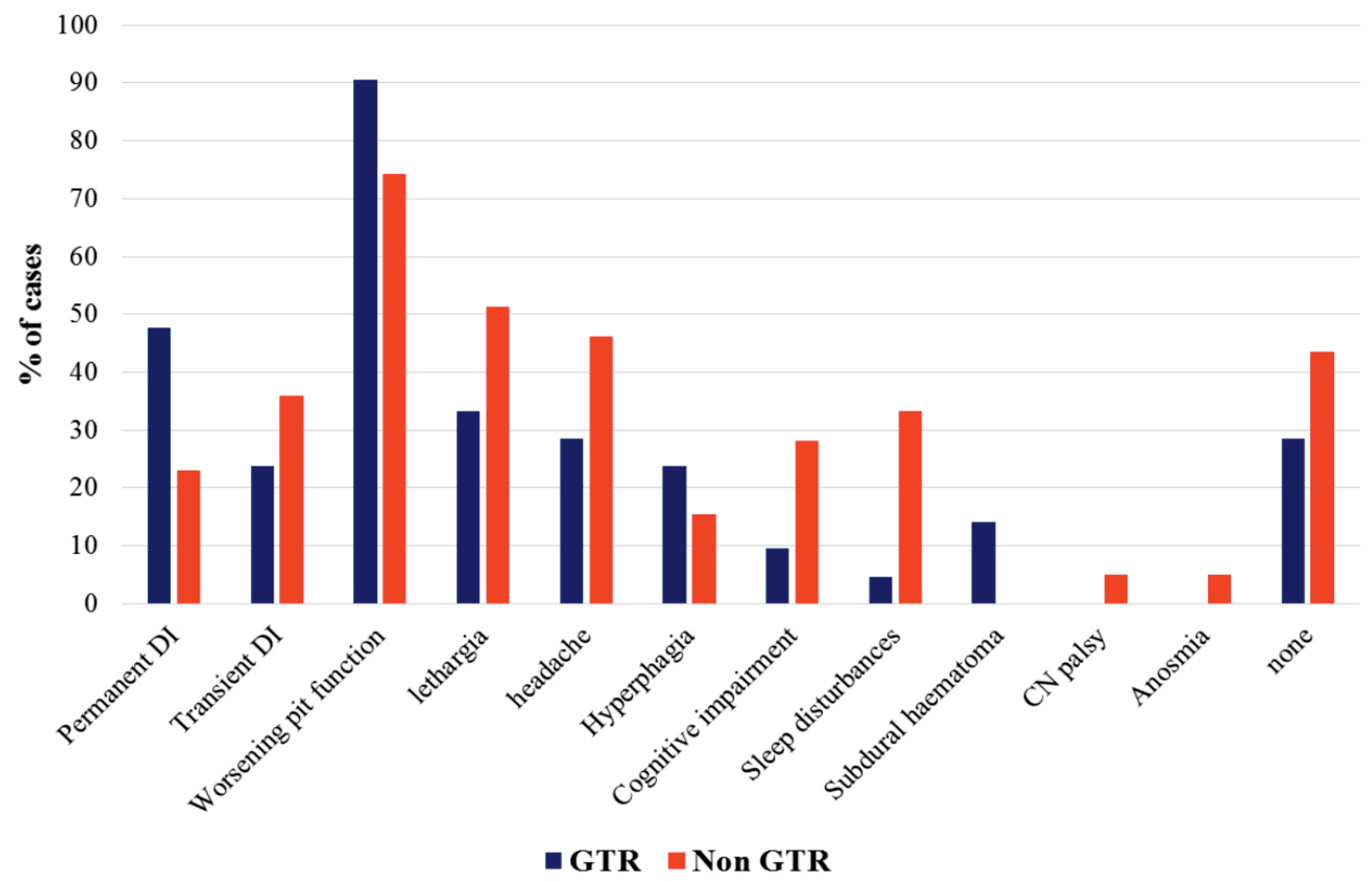

Figure 1. Postsurgical complications in the GTR and non-GTR subgroups * $p \leq 0.05$.

$\%$ of cases

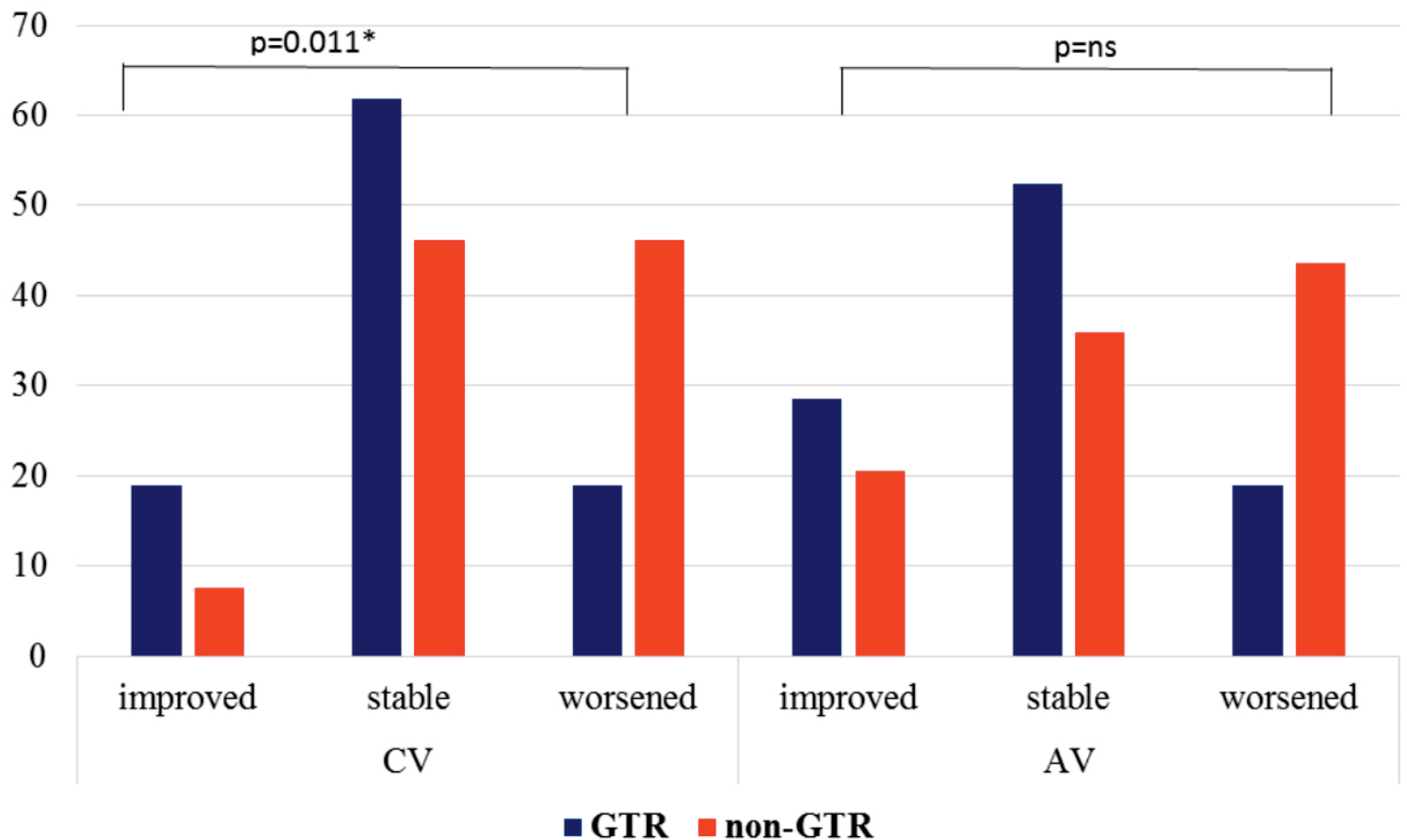

Figure 2. Evolution of visual function after surgery in the two subgroups. 


\section{DISCUSSION}

Numerous factors (related to tumor characteristicslocation, invasion, calcifications and/or cystic components; patient, the expertise of the surgical team in the treatment of these very challenging tumors) are involved in the surgical success of the intervention for craniopharyngioma and this is reflected in the very variable rate of GTR reportedin the literature: $18-84 \%$ of cases ${ }^{1}$.

In our cohort the rate of GTR is not impressive (35\%) but it is comparable to other very recently reported surgical series ${ }^{3}$. GTR was associated with significantly more important impairment in the functioning of both anterior and posterior pituitary (hypopituitarism, permanent diabetes insipidus) in our cohort, a finding similar to that reported by other researchers ${ }^{4}$. However important neurological and behavioural complications (headache, lethargia, sleep disturbances, cognitive impairment) were significantly more frequent in the non GTR group.

In most series reported in literature not only endocrinological but also visual and neurological impairment were significantly more frequent in GTR patients compared to those who obtained subtotal tumor resection, with or without postoperative radiotherapy ${ }^{4}$. The conclusion was not consistent: the very large retrospective study by Karavitaki et al. did not report significant differences in the functional outcomes and postsurgical morbidity between surgically cured cases and those with subtotal resection with the notable exception of visual deterioration which was less frequent in GTR cases $^{5}$. However, the bulk of reports pointing to the worse outcome in GTR patients led to the general recommendation that subtotal resection followed by radiotherapy should be the preferred approach, associated with improved immediate and long-term outcomes $^{6,7}$.

In our cohort the overall rate of complications was higher in the GTR subgroup, mainly due to worse- ning of the endocrinological function. While this is definitely important leading to long-term morbidity and quality of life impairment ${ }^{8}$ other neurological and visual outcomes are also of paramount importance. In our cohort the GTR cases had significantly better visual outcome compared to non-GTR cases and they also experienced lower rates of cognitive impairment and sleep problems after the surgical intervention. This increased overall neuropsychological morbidity was observed in all patients with craniopharyngioma but was previously found to be worse after total resection 9 . A significant particularity of our retrospective case series is the fact that the non-GTR cases mostly underwent partial rather than subtotal resection. This could support the idea that these tumors were particularly difficult to excise (although tumor size was similar to the GTR subgroup) thus explaining possibly also the significantly increased postoperative prevalence of several neurocognitive problems in these cases.

In conclusion, individualized intraoperative decision-making regarding the possibility of more aggressive versus limited surgery should be an essential part in the complex management of craniopharyngiomas. Apart from constantly improving personal skills and experience with these rare tumors, the neurosurgeon should constantly adapt his intervention plan to the tumor size, location, extension, structure and adherence to vital nearby structures in order to minimize postoperative morbidity.

\section{Compliance with ethics requirements:}

The authors declare no conflict of interest regarding this article.

The authors declare that all the procedures and experiments of this study respect the ethical standards in the Helsinki Declaration of 1975, as revised in 2008(5), as well as the national law. Informed consent was obtained from all the patients included in the study. 


\section{References}

1. Karavitaki, N., et al., Craniopharyngiomas. Endocr Rev, 2006 27(4): p. 371-97.

2. Fahlbusch, R., et al., Surgical treatment of craniopharyngiomas: experience with 168 patients. J Neurosurg, 1999. 90(2): p. 23750.

3. Radovanovic, I., et al., Expanded Endonasal Endoscopic Surgery in Suprasellar Craniopharyngiomas: A Retrospective Analysis of 43 Surgeries Including Recurrent Cases. Oper Neurosurg (Hagerstown), 2019.

4. Sughrue, M.E., et al., Endocrinologic, neurologic, and visual morbidity after treatment for craniopharyngioma. J Neurooncol, 2011. 101(3): p. 463-76.

5. Karavitaki, N., et al., Craniopharyngiomas in children and adults: systematic analysis of 121 cases with long-term follow-up. Clin Endocrinol (Oxf), 2005. 62(4): p. 397-409.
6. Scarzello, G., et al., Acute and late morbidity after limited resection and focal radiation therapy in craniopharyngiomas. J Pediatr Endocrinol Metab, 2006. 19 Suppl 1: p. 399-405.

7. Merchant, T.E., et al., Phase II trial of conformal radiation therapy for pediatric patients with craniopharyngioma and correlation of surgical factors and radiation dosimetry with change in cognitive function. J Neurosurg, 2006. 104(2 Suppl): p. 94-102.

8. Webb, S.M., et al., Management Of Endocrine Disease: Quality of life tools for the management of pituitary disease. Eur J Endocrinol, 2017. 177(1): p. R13-R26.

9. Fournier-Goodnight, A.S., et al., Neurocognitive functioning in pediatric craniopharyngioma: performance before treatment with proton therapy. J Neurooncol, 2017. 134(1): p. 97-105. 